\title{
NTRK2 Gene Rearrangement
}

National Cancer Institute

\section{Source}

National Cancer Institute. NTRK2 Gene Rearrangement. NCI Thesaurus. Code C131321.

A molecular abnormality indicating rearrangement of the NTRK2 gene. 